\title{
Pengaruh Keteladanan Kepala Sekolah, Iklim Kerja Organisasi, Kepuasan Kerja Terhadap Loyalitas Kerja Guru SMP Kecamatan Medan Amplas
}

\author{
Zufani, Belferik Manullang dan Abdul Muin Sibuea \\ Program Studi Administrasi Pendidikan, Pascasarjana Universitas Negeri Medan, 20221 \\ Sumatera Utara Indonesia \\ Email: Zufani.fani@gmail.com
}

\begin{abstract}
ABSTRAK
Penelitian ini bertujuan untuk mendeskripsikan dan mengetahui pengaruh keteladanan kepala sekolah terhadap kepuasan kerja, pengaruh iklim kerja organisasi terhadap kepuasan kerja, pengaruh keteladanan kepala sekolah terhadap loyalitas kerja, pengaruh iklim kerja organisasi terhadap loyalitas kerja, dan pengaruh kepuasan kerja terhadap loyalitas kerja SMP Swasta Kecamatan Medan Amplas. Penelitian ini menggunakan metode kuantitatif, model yang digunakan adalah analisis jalur (Path Analysis). Jumlah guruSMP Swasta yang ada di Kecamatan Medan Amplas yang berjumlah 232 guru diperoleh jumlah sampel sebesar 147 orang. Teknik sampling yang digunakan yaitu proportional random sampling. Teknik pengumpulan data dilakukan dengan menggunakan angket. Hasil dari penelitian ini ditemukan terdapat pengaruh langsung positif keteladanan kepala sekolah terhadap kepuasan kerja guru sebesar $10 \%$, terdapat pengaruh langsung positif iklim kerja organisasi terhadap kepuasan kerja guru sebesar $6,76 \%$, terdapat pengaruh langsung positif keteladanan kepala sekolah terhadap loyalitas kerja guru sebesar $5,29 \%$, terdapat pengaruh langsung positif iklim kerja organisasi terhadap loyalitas kerja guru sebesar $6,25 \%$, dan terdapat pengaruh langsung positif kepuasan kerja terhadap loyalitas kerja guru sebesar 3,24\%.
\end{abstract}

Kata Kunci : Keteladanan Kepala Sekolah, Iklim Kerja Organisasi, Kepuasan Kerja, Loyalitas Kerja

\begin{abstract}
This study aims to describe and know the influence of the school principal on job satisfaction, the influence of the work climate of the organization on job satisfaction, the influence of the school principal on work loyalty, the influence of organizational work climate on work loyalty, and the influence of job satisfaction on the work loyalty of Private SMP Medan Amplas districts. This research uses quantitative method, the model used is path analysis (Path Analysis). The number of private junior high school teachers in Medan Amplas district, amounting to 232 teachers, obtained a total sample of 147 people. The sampling technique used is proportional random sampling. Data collection techniques were conducted using a questionnaire. The result of this research found that there is a positive direct influence of school principal to teacher job satisfaction by $10 \%$, there is positive direct effect of work climate of organization toward teacher work satisfaction equal to $6,76 \%$, there is direct positive influence of exemplary headmaster to teacher work loyalty equal to 5, 29\%, there is a positive direct effect of work climate of organization to teacher work loyalty equal to 6,25\%, and there is positive influence of job satisfaction to teacher work loyalty 3,24\%.
\end{abstract}

Keywords: Principal Example, Working Organizational Climate, Job Satisfaction, Job Loyalty 


\section{A. PENDAHULUAN}

Pendidikan merupakan salah satu wahana untuk meningkatkan kualitas sumber daya manusia karena keberhasilan dunia pendidikan sebagai faktor penentu tercapainya tujuan pembangunan nasional di bidang pendidikan, yaitu mencerdaskan kehidupan bangsa..

Sebagai salah satu lembaga menyelenggarakan pendidikan secara formal, yaitu sekolah yang memiliki peranan yang sangat penting dalam mewujudkan tujuan pendidikan nasional melalui proses belajar mengajar. Sekolah merupakan institusi pendidikan yang di dalamnya terdapat beberapa komponen yang saling berkaitan. Adapun komponen-komponen tersebut ialah kepala sekolah, guru, siswa, staf administrasi, lingkungan, serta kurikulum (materi, metode, dan media). Komponenkomponen tersebut haruslah terwujud dengan kinerja yang strategis untuk dapat mencapai komitmen tujuan sekolah. Tujuan sekolah secara global dapat berupa tuntutan untuk mewujudkan kemampuan akademis tertentu, keterampilan, sikap, dan mental, serta kepribadian yang harus dimiliki peserta didik sebagai output dari proses pembelajaran.

Dalam rangka proses peningkatan mutu pendidikan diperlukan guru, baik secara individual maupun kolaboratif untuk melakukan sesuatu yang lebih baik agar pendidikan dan pembelajaran menjadi berkualitas. Guru sebagai tenaga pendidik merupakan pelaku utama dalam pelaksanaan pendidikan yang selalu berhadapan langsung dengan peserta didik yang sangat menentukan terhadap pencapaian keberhasilan pendidikan dalam rangka keberhasilan sumber daya manusia yang berkualitas.

Di dalam sekolah diharapkan guru-guru mempunyai sikap loyalitas yang tinggi terhadap organisasi dalam pelaksanaan tugas dan tanggung jawabnya terhadap sekolah. Loyalitas merupakan kesediaan guru untuk melanggengkan hubungan dengan organisasi, dengan mementingkan kepentingan organisasi dari pada kepentingan pribadinya, adanya rasa cinta dan tanggung jawab untuk berusaha memberikan pelayanan dan perilaku yang terbaik terhadap organisasi (sekolah).

Menurut Poerwopoespito (2004:214) mengatakan bahwa loyalitas kepada pekerjaan tercermin pada sikap karyawan yang mencurahkan kemampuan dan keahlian yang dimiliki, melaksanakan tugas dan bertanggung jawab, disiplin, serta jujur dalam bekerja. Sikap setia kepada perusahaan antara lain adalah jujur, mempunyai rasa memiliki terhadap perusahaan, mengerti kesulitan perusahaan, bekerja lebih dari yang diminta perusahaan, menciptakan suasana menyenangkan di perusahaan, menyimpan rapat rahasia perusahaan, menjaga dan meninggikan citra perusahaan, hemat, tidak unjuk rasa dan tidak apriori terhadap perusahaan.

Menurut Rasimin (2006:178), "Loyalitas adalah kesetiaan, pengabdian, dan kepercayaan yang diberikan atau ditujukan kepada seseorang atau lembaga, yang didalamnya terdapat rasa cinta dan tanggung jawab untuk berusaha memberikan pelayanan dan perilaku yang terbaik. Sehingga kemauan kerja sama yang berarti kesediaan pengorbanan diri, kesediaan melakukan pengawasan diri, dan kemauan untuk menonjolkan kepentingan diri sendiri. Kesediaan untuk mengorbankan diri ini melibatkan adanya kesadaran untuk mengabdikan diri kepada suatu organisasi, pengabdian ini akan menyongkong peran seseorang dalam suatu organisasi.

Guru yang memiliki loyalitas dalam bekerja dapat terlihat dari sikap yang ditunjukkan terhadap institusi sekolah berupa sikap senang sebagai guru, bangga terhadap sekolah, peduli terhadap sekolah, dan bertanggung jawab dalam tugas mengajar, mampu melibatkan diri sepenuhnya kepada aktivitas-aktivitas sekolah, siap dan bersedia mempertahankan nama baik sekolah. Saydam (1996 : 417) mengemukakan seseorang yang memiliki loyalitas baik memperlihatkan perilaku : 1) tidak senang melihat 
perbuatan cenderung merugikan sekolah, 2) bersedia turun tangan untuk mencegah halhal yang merugikan sekolah, 3) bersedia mengorbankan kepentingan pribadinya, waktunya, tenaganya untuk kemajuan sekolah, 4) tidak mau berbuat hal-hal yang mengarah pada hal yang merusak sekolah, 5) suka bekerja keras, kreatif, dan selalu ingin berbuat yang terbaik bagi sekolah, dan 6) merasa bangga atas prestasi yang dicapai sekolah.

Namun pada kenyataannya hal tersebut jauh dari harapan, berdasarkan studi pendahuluan yang dilakukan menurut pengamatan peneliti pada bulan di Februari 2016 di SMP Swasta Kecamatan Medan Amplas, ditemukan masalah pada rendahnya loyalitas guru disini juga bermasalah antara lain : 1) guru tidak senang terhadap profesinya, hal ini menunjukkan bahwa guru terkesan bekerja dengan cara terpaksa, terlihat guru jarang sekali memberikan penjelasan materi pelajaran kepada peserta didik, 2) posisi guru dalam mengajar yang tidak sesuai dengan bidangnya, hal ini menunjukkan bahwa masih ada guru mengajar tidak sesuai dengan bidang pendidikan yang ia tempuh selama di perguruan tinggi, 3) sarana dan prasarana sekolah belum memadai, 4) guru jarang berpartisipasi dalam semua kegiatan yang diselenggarakan sekolah tempatnya bekerja, 5) masih banyak guru mengeluh dalam melaksanakan tugas tambahan yang diberikan kepala sekolah di dalam maupun di luar jam kerja, dan 6) tanggung jawab kerja guru masih rendah. Selain itu, masih ada guru datang terlambat, sebagian guru tidak membuat rancangan pembelajaran (RPP) melainkan mengkopi dari guru lain, atau mendowload dari internet, sebagian guru tidak menggunakan metode dan strategi pembelajaran yang bervariasi, guru mengajar dengan cara masih menonton, masih ada guru tidak menggunakan media pembelajaran alasan tidak mampu membuatnya, tidak ada biaya dan merasa tidak punya waktu untuk membuatnya. Kemudian ketidak kompakan atau kebersamaan di antara guru masih kurang. Hal ini terlihat dari ketidak pedulian guru terhadap keadaan atau situasi yang ada di lingkungan sekolah.

Hal ini juga ditemukan di sekolah SMA Negeri 2 Pematang Siantar, penelitian yang dilakukan Akhyar berdasarkan observasi yang ditemukan beberapa data mengindentifikasikan rendahnya loyalitas kerja guru yaitu : adanya kecenderungan guru lebih terobsesi mengejar kesejahteraan materi dari pada pengabdiannya sebagai Pegawai Negeri Sipil (PNS), sekitar 26 (86,67\%) guru lebih terobsesi mengejar kesejahteraan dari pada menyisihkan waktu luang untuk memberikan bimbingan belajar kepada siswa. Ini terlihat jika ada guru tidak hadir, guru yang memiliki waktu luang tidak masuk untuk memberikan bimbingan kepada siswa dengan alasan bukan tanggung jawabnya. Selain itu ketika upacara berlangsung masih ada guru yang terlambat dan keterlambatan tersebut terlihat oleh siswa.

Seperti juga dikemukakan oleh Nitisemito (1991:167), "kurangnya loyalitas guru dalam menjalankan tugasnya dipengaruhi oleh gaji yang kurang, tidak tercukupinya kebutuhan rohani, suasana kerja, posisi jabatan yang tidak tepat, kesempatan berprestasi, rasa aman, dan penyediaan fasilitas yang kurang menyenangkan”. Faktor-faktor tersebut tentu memiliki keterkaitan dengan kepemimpinan kepala sekolah, sebab peranan kepala sekolah memiliki kemampuan membangkitkan semangat kerja guru, dan menciptakan suasana yang kondusif, serta meningkatkan kepuasan kerja guru agar guru loyal dalam pekerjaannya di sekolah tersebut.

Hal yang senada di lakukan Aisyatur Rahma dan Elizabeth Ranu tentang"Peran Budaya dan Iklim Kerja Terhadap Loyalitas Kerja Pegawai Bagian Umum Sekretariat Daerah Kabupaten Lamongan" dalam observasinya bahwa ada beberapa pegawai yang kurang menaati peraturan di kantor, beberapa pegawai masih kurang memiliki etika dalam bekerja yang baik, belum tersedianya sarana dan prasarana yang memadai 
sehingga dalam bekerja kurang optimal, adanya komitmen yang masih kurang dalam bekerja, dan masih kurangnya komunikasi antara teman sekerja.

Robbins (2006:448), menyatakan bahwa faktor kepemimpinan, faktor lingkungan, dan faktor kontingensi bawahan dapat mempengaruhi kepuasan seseorang dalam bekerja, artinya, bahwa puas tidaknya seseorang dapat dipengaruhi oleh faktor pemimpin, lingkungan, atau budaya dalam organisasinya serta pengaruh perilaku karyawan.

Keteladanan kepala sekolah adalah sikap dan tingkah laku pemimpin, ucapan maupun perbuatan yang dapat di tiru dan di teladani oleh bawahannya. Kepala sekolah memainkan peranan penting dalam upaya peningkatan kualitas kerja guru. Wahjosumidjo (2005:83) mengatakan kepala sekolah merupakan seorang tenaga fungsional guru yang diberi tugas untuk memimpin suatu sekolah di mana diselenggarakan proses belajar mengajar, atau tempat dimana terjadi interaksi antara guru yang memberi pelajaran dan murid yang menerima pelajaran.

Zazin (2011:214) mengatakan kepala sekolah merupakan kepemimpinan yang tertinggi di sekolah yang sangat berpengaruh, bahkan sangat menentukan terhadap mutu pendidikan di sekolah. Kepemimpinan kepala sekolah adalah suatu kemampuan dan kesiapan kepala sekolah untuk mempengaruhi, membimbing, mengarahkan, dan menggerakkan staf sekolah agar dapat bekerja secara efektif dalam rangka mencapai tujuan pendidikan dan pengajaran yang telah ditetapkan, atau bisa dikatakan bantuan yang diberikan oleh kepala sekolah terhadap penetapan pencapaian tujuan pendidikan. Menurut Mulyasa (2009:98) kepala sekolah sedikitnya mempunyai peran dan fungsinya sebagai Edukator, Manajer, Administrator, Supervisor, Leader, Inovator dan Motivator.

Kepala sekolah sebagai pemimpin memberikan petunjuk dan pengawasan serta meningkatkan kemauan tenaga pendidik, membuka komunikasi dua arah, dan mendelegasikan tugas. Sebagaimana juga dikatakan Wahjosumidjo (2013:110) mengemukakan kepala sekolah sebagai pemimpin harus memiliki karakter khusus mencakup : 1) kepribadian, 2) keahlian dasar, 3) pengalaman dan pengetahuan profesional, 4) diklat dan keterampilan profesional, dan 5) pengetahuan administrasi dan pengawasan yang profesional.

Iklim kerja organisasi juga mempengaruhi loyalitas kerja guru, iklim organisasi merupakan lingkungan kerja yang bersifat psikis yang tidak terlihat nyata tetapi dapat dirasakan oleh para anggotanya di dalam organisasi tersebut. Hal ini merupakan konsep yang menunjukkan isi dan kekuatan dari pengaruh antara nilai, norma, sikap perilaku dan perasaan dari anggota yang ada dalam organisasi. Iklim organisasi juga tidak terlepas dari sifat atau ciri yang terdapat di dalam suatu lingkungan kerja dan timbul karena kegiatan organisasi. Sehingga, iklim organisasi dapat dianggap sebagai keperibadian organisasi seperti yang dirasakan oleh para anggotannya (Steers, 1977:121).

Faktor-faktor sikap, nilai, perilaku dan motif-motif yang dimiliki individu disadari ikut berperan penting dalam proses perseptual iklim organisasi tempat individu bekerja. Pengaruh iklim terhadap perilaku karena dilandaskan oleh pendapat bahwa pada dasarnya orang cenderung bertingkah berdasarkan pandangan mengenai lingkungan dan tidak selalu berdasarkan keadaan bagaimana keadaan lingkungan sebenarnya. Artinya iklim menjadi dasar bagi individu-individu untuk menentukan sikap dan perilakunya didalam organisasi, semakin banyak kesesuaian yang terjadi, maka akan semakin baik atau positif menurut individu.

Selain keteledanan kepala sekolah dan iklim organisasi, faktor kepuasan kerja juga mempengaruhi loyalitas kerja guru. Kepuasan kerja merupakan hasil persepsi seseorang terhadap seberapa baik pekerjaan akan memenuhi harapan mereka. Menurut Robbins dan Judge (2008:107) mengartikan kepuasan kerja sebagai suatu perasaan 
positif yang timbul dalam diri seseorang terhadap pekerjaannya yang merupakan hasil dari evaluasi karakteristik dirinya.

Wirawan (2013:698) mengartikan kepuasan kerja adalah persepsi orang mengenai berbagai aspek dari pekerjaannya. Dimana persepsi ini dapat diartikan berupa perasaan dan sikap seseorang terhadap pekerjaan yang sedang digelutinya. Perasaan dan sikap ini bisa menimbulkan dampak positif dan negatif, sikap positif ini dapat diartikan bahwa seseorang merasa puas terhadap pekerjaannya sebaliknya sikap negatif menunjukkan bahwa orang tersebut tidak puas dengan pekerjaannya. Handoko (2001:193) mengatakan kepusasan kerja merupakan keadaan emosional yang menyenangkan atau tidak menyenangkan dengan mana para karyawan memandang pekerjaan mereka. Dari pendapat-pendapat tersebut disimpulkan bahwa kepuasan kerja adalah perasaan seseorang terhadap pekerjaannya yang menimbulkan sikap posistif dan negatif atau merasa puas atau tidak puas terhadap pekerjaannya.

Berdasarkan kenyataan, pendapat para ahli dan hasil penelitian yang dipaparkan pada latar belakang masalah di atas, maka dapat disintesiskan bahwa melalui keteladanan kepala sekolah, iklim organisasi, dan kepuasan kerja akan mampu menghasilkan loyalitas kerja guru yang lebih baik pula.

\section{B. TINJAUAN PUSTAKA}

\section{Loyalitas Kerja}

Menurut Nitisemito (1991:136) mengatakan bahwa loyalitas adalah kesetiaan terhadap organisasi tempat bekerja, seringkali dipakai syarat untuk promosi. Sebagaimana yang dikemukakan Sudimin (2003:5) yang mengatakan bahwa loyalitas berarti kesediaan karyawan dengan seluruh kemampuan, keterampilan, pikiran, dan waktu untuk ikut serta mencapai tujuan perusahaan serta tidak melakukan tindakantindakan yang merugikan organisasi selama orang itu masih berstatus sebagai karyawan.

Selanjutnya, Saydam (1996:485) mengemukakan bahwa loyalitas adalah tekad dan kesanggupan mentaati, melaksanakan dan mengamalkan sesuatu yang dipatuhi dengan penuh kesadaran dan tanggung jawab, tekad dan tingkah laku sehari-hari dalam melaksanakan tugas. Sedangkan menurut Poerwopoespito (2004:214) mengatakan bahwa loyalitas kepada pekerjaan tercermin pada sikap karyawan yang mencurahkan kemampuan dan keahlian yang dimiliki, melaksanakan tugas dan bertanggung jawab, disiplin, serta jujur dalam bekerja. Lebih lanjut Poerwopoespito mengatakan sikap karyawan sebagai bagian perusahaan yang paling utama adalah loyal. Sikap ini diantaranya tercermin dari terciptanya suasana yang menyenangkan dan mendukung tempat kerja, menjaga citra perusahaan dan adanya kesediaanya untuk bekerja dalam jangka waktu yang lebih panjang.

Berdasarkan pernyataan di atas dapat disimpulkan bahwa loyalitas kerja adalah sikap kesetiaan, kesanggupan melaksanakan dan mengamalkan sesuatu disertai dengan tanggung jawab dan kesadaran, serta berusaha membela perusahaan/lembaga/sekolah dari tindakan yang merugikan organisasi. Mengacu pada pengertian tersebut maka loyalitas memiliki unsur antara lain : adanya sikap kesetiaan, kesadaran melaksanakan, tanggung jawab, serta berusaha menjaga nama baik perusahaan.

\section{Keteladanan Kepala Sekolah}

Keteladan berasal dari kata 'teladan' yaitu suatu (perbuatan, barang dan sebagainya) yang patut ditiru dan dicontoh. Keteladanan yang dimaksud disini adalah sikap dan tingkah laku pemimpin, ucapan maupun perbuatan yang dapat di tiru dan di 
teladani oleh bawahannya. Keteladanan melakukan apa yang harus dilakukan dan tidak melakukan hal-hal yang tidak boleh dilakukan, baik karena keterikatan kepada peraturan undang-undang yang berlaku maupun karena limitasi yang ditentukan oleh nilai-nilai moral, etika dan sosial (Siagian, 2003:105).

Sebagaimana yang dikatakan Edward seperti dikutip Wahjosmidjo, (2001:78) yakni disciplinary activity includes any action which attempts to promote cooperation and abediaence to order, rules and regulation". Disiplin itu meliputi aktivitas, tindakan yang dilakukan dalam usaha memuaskan kerjasama, patuh terhadap ketentuan yang berlaku dan terhadap tugas yang dibebankan. Keteladanan menghendaki konsistensi antara perkataan, sikap, tingkah laku, dan perbuatan. Seorang kepala sekolah harus mampu mensinergikan keseluruhan sikapnya sesuai dengan norma yang berlaku, baik yang berkaitan dengan kode etik guru maupun tata tertib yang di sekolah dimana ia mengabdi. Sehingga para guru menjadikannya sebagai teladan, panutan dan mengikutinya. Setiap orang memahami bahwa keteladanan merupakan salah satu karakteristik penting bagi keberhasilan seorang pemimpin.

Dalam teori kepemimpinan keteladanan, Kouzes dan Posner (1999:32), mengatakan bahwa pemimpin melaksanakan lima praktek kepemimpinan teladan yaitu : 1) mencontohkan cara, 2) menginspirasi visi bersama, 3) menentang proses, 4) memampukan orang lain untuk bertindak, dan 5) mendorong hati.

Kepala sekolah selain berfungsi sebagai pemimpin juga berfungsi sebagai edukator (pendidik), manajer, administrator, supervisor, leader, inovator dan motivator (Mulyasa, 2009:98). Kepala sekolah sebagai edukator adalah merupakan tugas utama yang harus dilakukan. Sebagaimana pendapat tersebut, bahwa kepala sekolah adalah guru yang diberikan tugas tambahan sebagai kepala sekolah. Kegiatan belajar mengajar merupakan inti dari proses pendidikan dan guru pelaksana dan pengembang kurikulum di sekolah. Kepala sekolah yang menunjukkan komitmen tinggi dan fokus terhadap pengembangan kurikulum dan kegiatan belajar mengajar di sekolahnya tentu saja akan sangat memperhatikan tingkat kompetensi yang dimilki gurunya sekaligus juga akan senantiasa berusaha menfasilitasi dan mendorong agar para guru dapat secara terus menerus meningkatkan kompetensinya, sehingga kegiatan belajar mengajar dapat berjalan efektif dan efisien.

Kepala sekolah sebagai manajer pada hakekatnya adalah seorang perencana, organisator, pemimpin, dan pengendali. Keberadaan manajer pada suatu organisasi diperlukan, sebab sebagai alat untuk mencapai tujuan memerlukan seorang manajer yang mampu untuk merencanakan, mengorganisasikan, memimpin dan mengendalikan agar organisasi dapat mencapai tujuan yang telah ditetapkan.

Sebagai administrator, kepala sekolah dalam lembaga pendidikan bertanggung jawab terhadap kelancaran pelaksanaan dan pengajaran di sekolahnya. Oleh karena itu, untuk dapat melaksanakan tugasnya dengan baik, kepala sekolah hendaknya memahami, menguasai, dan mampu meloaksanakan kegiatan-kegiatan yang berkenaan dengan fungsinya sebagai administrator pendidikan (Purwanto 2009:106.)

Selanjutnya, kepala sekolah bertindak sebagai supervisor. Supervisi merupakan kegiatan membina dan dengan membantu pertumbuhan agar setiap orang mengalami peningkatan pribadi dan profesinya. Menurut Mukhtar dan Iskandar (2013:44), supervisi adalah suatu usaha mengkoordinasi dan membimbing secara kontinu pertumbuhan guruguru di sekolah baik secara individu maupun kelompok. Hakekatnya segenap bantuan yang ditujukan pada perbaikan-perbaikan dan pembinaan aspek pengajaran. Tugas kepala sekolah sebagai supervisor terlihat dari penyusunan program supervisi kelas, 
melaksanakan supervisi kelas dan kemampuan memanfaatkan hasil supervisi tersebut untuk pengembangan sekolah.

Kepala sekolah sebagai seorang pemimpin, menurut Wahjosumidjo (2013:83) dalam praktek organisasi, kata "memimpin"mengandung konotasi menggerakkan, mengarahkan, membimbing, melindungi, membina, memberikan teladan, memberikan dorongan, memberikan bantuan, dan sebagainya.

Kepala sebagai inovator harus memiliki strategi yang tepat untuk menjalin hubungan yang harmonis dengan lingkungan, mencari gagasan baru, mengintegrasikan setiap kegiatan, memberikan teladan kepada seluruh tenaga kependidikan di sekolah, dan mengembangkan model-model pembelajaran yang inovatif.

Sebagai motivator, kepala sekolah harus memiliki strategi yang tepat untuk memberikan motivasi kepada para tenaga kependidikan dalam melakukan berbagai tugas dan fungsinya. Motivasi ini dapat ditumbuhkan melalui pengaturan lingkungan fisik, pengaturan suasana kerja, disiplin, dorongan, penghargaan secara efektif, dan penyediaan berbagai sumber belajar melalui pengembangan Pusat Sumber Belajar (PSB) (Mulyasa, 2009:188-120).

Berdasarkan uraian diatas dapat disimpulkan bahwa kepala sekolah merupakan seorang pemimpin terpandang di lingkungan masyarakat sekolah, ia adalah pusat teladan bagi warga sekolah dan warga masyarakat di sekitar sekolah, karena itu kepala sekolah wajib melaksanakan petunjuk tentang usaha peningkatan ketahanan sekolah, dan juga kepala sekolah memiliki tanggung jawab sebagai pemimpin di bidang pengajaran dan pengembangan kurikulum, administrasi personalia staf, hubungan masyarakat, dan perlengkapan organisasi sekolah.

\section{Iklim Kerja Organisasi}

Istilah iklim organisasi (organizational climate) pertama kalinya dipakai oleh Kurt Lewin pada tahun 1930-an, yang menggunakan istilah iklim psikologi (psychological climate).

Istilah iklim organisasi dipakai oleh R. Tagiuri dan G. Litwin (Wirawan, 2007:121), yang menyatakan iklim organisasi merupakan kualitas lingkungan internal organisasi yang secara relatif terus berlangsung dialami oleh anggota organisasi, memengaruhi perilaku mereka dan dapat dilukiskan dalam pengertian satu set karakteristik atau sifat organisasi. Sedangkan menurut Croft seperti dikutip Sagala (2008:129) mengemukakan bahwa iklim organisasi yang berkualitas ditandai adanya suasana penuh semangat dan adanya daya hidup, memberikan kepuasan kepada anggota organisasi. Jadi, iklim organisasi adalah rangkaian sifat lingkungan kerja, yang dinilai langsung atau tidak langsung oleh karyawan yang dianggap menjadi kekuatan utama dalam mempengaruhi perilaku karyawan.

Iklim organisasi menurut Steers (1997:120) mengatakan bahwa suatu sifat-sifat atau ciri yang dirasa terdapat dalam lingkungan kerja dan timbul karena kegiatan organisasi, yang dilakukan secara sadar atau tidak, yang dianggap mempengaruhi tingkah laku kemudian. Dengan perkataan lain iklim dapat dipandang sebagai "kepribadian" dari suatu organisasi seperti yang dilihat oleh para anggotanya. Newstrom dan Davis (1996:21) mengatakan bahwa iklim organisasi adalah lingkungan manusia yang di dalamnya para pegawai suatu organisasi melakukan pekerjaan mereka. Sedangkan menurut Payne dan Pugh seperti dikutip Muhammad (2009:82), mendefenisikan iklim kerja organisasi sebagai suatu konsep yang merefleksikan isi dan kekuatan dari nilai-nilai umum, norma, sikap, tingkah laku dan perasaan anggota terhadap suatu sistem sosial. 
Selanjutnya menurut Robert Stringer seperti dikutip Wirawan (2007: 131), mengatakan iklim organisasi dapat dilukiskan dan diukur terdapat enam dimensi yang diperlukan yaitu : (1) struktur, (2) standar-standar, (3) tanggung Jawab, (4) penghargaan, (5) dukungan, dan (6) komitmen.

Steers (1977:122) mengungkapkan ada sepuluh dimensi iklim organisasi yang dapat diukur yaitu : (1) struktur tugas, (2) hubungan imbalan-hukuman, (3) sentralisasi keputusan, (4) tekanan pada prestasi, (5) tekanan pada latihan dan pengembangan,(6) keamanan versus resiko, (7) keterbukaan versus ketertutupan,(8) status dan semangat,(9) pengakuan dan umpan balik, dan (10) kompetensi dan keluwesan organisasi secara umum.

Sementara itu Litwin dan Stringer seperti dikutip Muhammad (2009:83) juga memberikan dimensi iklim organisasi yaitu : (1) rasa tanggung jawab, (2) standar atau harapan tentang kualitas pekerjaan, (3) ganjaran atau reward, (4) rasa persaudaraan, dan (5) semangat tim.

Berdasarkan pernyataan di atas dapat disimpulkan bahwa iklim organisasi adalah persepsi anggota organisasi dan mereka secara tetap berhubungan dengan organisasi seperti hubungan antar kepala sekolah dan guru, hubungan sesama guru, dan hubungan antar guru dan siswa mengenai apa yang terjadi lingkungan organisasi yang mempengaruhi sikap dan perilaku dan kinerja anggota organisasi.

\section{Kepuasan Kerja}

Menurut Colquitt, et al. (2009:64) mengatakan kepuasan kerja adalah suatu pernyataan emosi yang menyenangkan yang dihasilkan dari penghargaan terhadap pekerjaan seseorang dan apa yang anda rasakan tentang pekerjaan anda dan apa yang anda pikirkan tentang pekerjaan anda.

Menurut Kinicki dan Kreitner (2001:271) kepuasan kerja adalah suatu efektivitas atau respons emosional terhadap berbagai aspek pekerjaan. Menurut Luthans (2005:212) dalam bukunya Organizational Behavior mengutip pendapat Locke bahwa kepuasan kerja merupakan keadaan emosional positif dari seseorang yang ditimbulkan dari penghargaan atas sesuatu pekerjaan yang dilakukannya. Dikatakan lebih lanjut bahwa kepuasan kerja merupakan hasil dari prestasi seseorang terhadap sampai seberapa baik pekerjaannya menyediakan sesuatu yang berguna baginya.

Menurut Robbins dan Judge (2008:107) mengartikan kepuasan kerja sebagai suatu perasaan positif yang timbul dalam diri seseorang terhadap pekerjaannya yang merupakan hasil dari evaluasi karakteristik dirinya. Kepuasan terjadi apabila kebutuhankebutuhan individu sudah terpenuhi dan terkait derajat kesukaan dan ketidaksukaan dikaitkan dengan karyawan, merupakan sikap umum yang dimiliki oleh karyawan yang erat kaitannya dengan imbalan-imbalan yang mereka yakini akan mereka terima setelah melakukan sebuah pengorbanan. Gibson (2002 : 464 - 465) mengemukakan bahwa kepuasan kerja tergantung pada hasil instrinsik, ekstrinsik, dan persepsi pemegang kerja pada pekerjaannya, sehingga kepuasan kerja adalah tingkat di mana seseorang merasa positif atau negatif tentang berbagai segi dari pekerjaan,

tempat kerja, dan hubungan dengan teman kerja.

Menurut Newstrom (2007:206) mengatakan bahwa kepuasan kerja adalah suatu seperangkat perasaan menyenangkan atau tidak menyenangkan dan emosi karyawan melihat pekerjaan mereka. Sedangkan menurut Hasibuan (2013:202) mengatakan bahwa kepuasan kerja adalah sikap emosional yang menyenangkan dan mencintai pekerjaannya. Sikap ini mencerminkan oleh moral kerja, kedisiplinan dan prestasi kerja. Kepuasan kerja dinikmati dalam pekerjaan, luar pekerjaan, dan kombinasi dalam dan luar pekerjaan 
Berdasarkan pernyataan diatas dapat ditarik kesimpulan bahwa kepuasan kerja merupakan sesuatu yang bersifat individual. Setiap individu memiliki tingkat kepuasan yang berbeda-beda sesuai dengan sistem nilai yang berlaku pada dirinya. Makin tinggi penilaian terhadap kegiatan dirasakan sesuai dengan keinginan individu, maka makin tinggi kepuasannya terhadap kegiatan tersebut. Jadi secara garis besar kepuasan kerja dapat diartikan sebagai hal yang menyenangkan atau tidak menyenangkan yang mana pegawai memandang pekerjaannya.

\section{METODE}

Pendekatan analisis yang digunakan dalam penelitian ini adalah analisis jalur (path analisis) atau sering disebut dengan pola hubungan sebab akibat. Penelitian ini juga menggunakan kajian korelatif dengan menempatkan variabel.

Subjek penelitian ini adalah 232 orang guru di SMP Swasta Kecamatan Medan Amplas. Peneliti mengambil jumlah sampel dengan menggunakan nomogram Harry King dengan peluang kekeliruan atau taraf signifikansi $\alpha=0,05$ dengan sampel 147 orang. Teknik pengambilan sampel penelitian digunakan dengan cara proportional random sampling. Pengumpulan data dalam penelitian ini menggunakan kuesioner loyalitas kerja, keteladanan kepala sekolah, iklim kerja dan kepuasan kerja yang berbentuk skala Likert.

\section{HASIL PENELITIAN DAN PEMBAHASAN}

\section{Hasil}

Dalam uji hipotesis variabel ada lima hipotesis yang akan diuji yaitu : 1) pengaruh keteladanan kepala sekolah terhadap kepuasan kerja, 2) pengaruh iklim kerja organisasi terhadap kepuasan kerja, 3) pengaruh keteladanan kepala sekolah terhadap loyalitas kerja, 4) pengaruh iklim kerja organisasi terhadap loyalitas, 5) pengaruh kepuasan kerja terhadap loyalitas kerja

Pengujian persyaratan analisis data dalam penelitian ini adalah uji normalitas, uji linieritas dan keberartian. Berdasarkan hasil uji normalitas data untuk setiap variabel penelitian didapatkan nilai signifikansi> 0,05, sehingga dapat disimpulkan bahwa data Keteladanan Kepala Sekolah (X1), Iklim Kerja Organisasi(X2), Kepuasan Kerja (X3), terhadap Loyalitas Kerja (X4) adalah berdistribusi normal.

Berdasarkan hasil uji linieritas untuk setiap variabel endogenus atas skor variabel eksogenus didapatkan nilai signifikansi > 0,05, sehingga dapat disimpulkan bahwa semua bentuk regresilinier. Berdasarkan hasil uji keberartian untuk setiap variabel endogenus atas skor variabel eksogenus didapatkan nilai signifikansi $<0,05$, sehingga dapat disimpulkan bahwa semua koefisien arah regresi berarti. Selanjutnya, dengan dilakukan uji korelasi dan uji hipotesis sehingga didapatkan koefisien korelasi dan koefisien jalur antara variabel eksogenus.Hasil perhitungan koefisien korelasi antar variabel penelitian dan perhitungan koefisien jalur dilihat pada tabel 1.

Tabel 1.Hasil Koefisien Korelasi (r)dan Perhitungan Koefisien Jalur ( $\rho$ )

\begin{tabular}{|l|c|}
\hline Koefisien Korelasi & Koefisien Jalur \\
\hline$r_{12}=0,172>0,162$ & $\rho_{21}=0,172$ \\
\hline$r_{13}=0,357>0,162$ & $\rho_{31}=0,313$ \\
\hline$r_{23}=0,309>0,162$ & $\rho_{32}=0,255$ \\
\hline$r_{14}=0,337>0,162$ & $\rho_{41}=0,229$ \\
\hline
\end{tabular}




\begin{tabular}{|l|l|}
\hline$r_{24}=0,343>0,162$ & $\rho_{42}=0,247$ \\
\hline$r_{34}=0,340>0,162$ & $\rho_{43}=0,182$ \\
\hline
\end{tabular}

Pada hipotesis pertama, perhitungan pengujian diperoleh hasil besarnya koefisien jalur $\rho_{31}=0,31$, selanjutnya dilakukan uji tdiperoleh harga $t_{\text {hitung }}=4,49$. Harga ini dikonsultasikan dengan $\mathrm{t}_{\text {tabel }}$ dengan $\mathrm{N}=147$ pada taraf $5 \%=1,98$. Hal ini menunjukkan bahwaHo ditolak dan Ha diterima yang artinya koefisien jalur adalah signifikansi.

Pada hipotesis kedua,perhitungan pengujian diperoleh hasil besarnya koefisien jalur $\rho_{32}=0,26$, selanjutnya dilakukan uji $t_{\text {hitung }}=3,64$. Harga ini dikonsultasikan dengan $\mathrm{t}_{\text {tabel }}$ dengan $\mathrm{N}=147$ pada taraf $5 \%=1,98$. Hal ini menunjukkan bahwa Ho ditolakdan Ha diterima yang artinya koefisien jalur adalah signifikansi.

Pada hipotesis ketiga,perhitungan pengujian diperoleh hasil besarnya koefisien jalur $\rho_{41}=0,23$, selanjutnya dilakukan uji $t_{\text {hitung }}=3,14$. Harga ini dikonsultasikan dengan $\mathrm{t}_{\text {tabel }}$ dengan $\mathrm{N}=147$ pada taraf $5 \%=1,98$. Hal ini menunjukkan bahwaHo ditolak dan Ha diterima yang artinya koefisien jalur adalah signifikansi.

Pada hipotesis keempat,perhitungan pengujian diperoleh hasil besarnya koefisien jalur $\rho_{42}=0,25$, selanjutnya dilakukan uji $t_{\text {hitung }}=3,53$. Harga ini dikonsultasikan dengan $\mathrm{t}_{\text {tabel }}$ dengan $\mathrm{N}=147$ pada taraf $5 \%=1,98$. Hal ini menunjukkan bahwaHo ditolak dan Ha diterima yang artinya koefisien jalur adalah signifikansi.

Pada hipotesis kelima, perhitungan pengujian diperoleh hasil besarnya koefisien jalur $\rho_{43}=0,18$, selanjutnya dilakukan uji $t_{\text {hitung }}=2,38$. Harga ini dikonsultasikan dengan

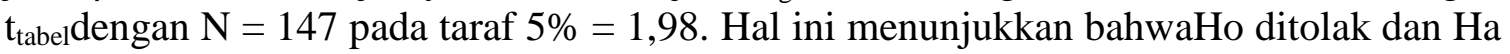
diterima yang artinya koefisien jalur adalah signifikansi.

maka dapat digambarkan diagram jalur model penelitian seperti pada Gambar 1 sebagai berikut

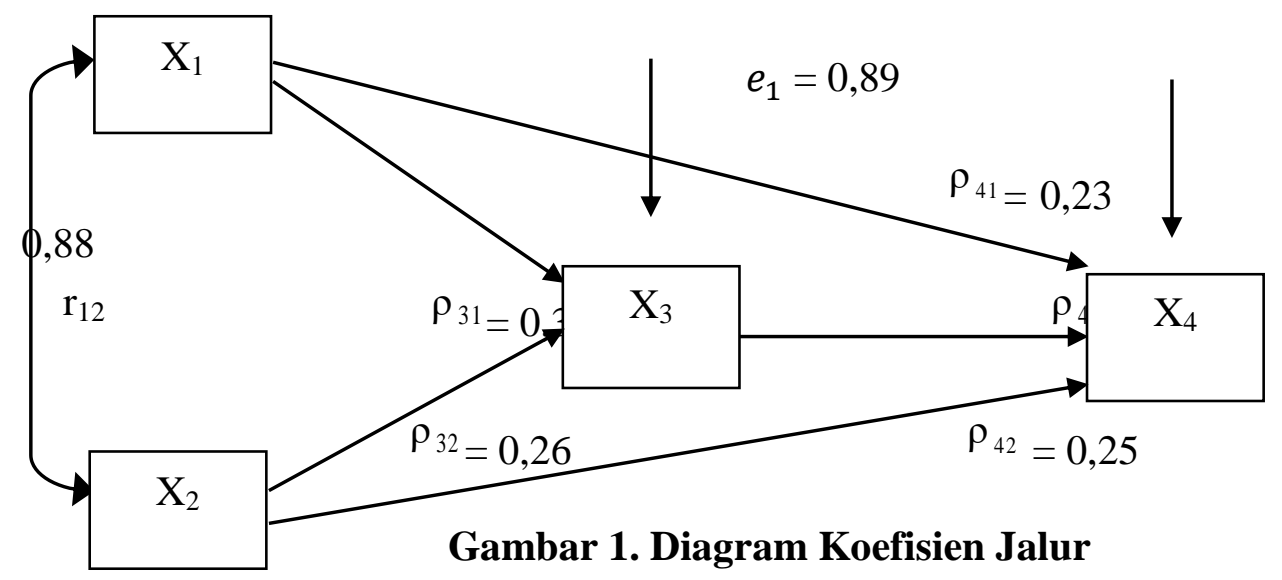

\section{Keterangan :}

$\mathrm{X}_{1} \quad=$ Keteladanan Kepala Sekolah

$\mathrm{X}_{2}=$ Iklim Kerja Organisasi

$\rho_{31}=$ Pengaruh $\mathrm{X}_{3}$ dan $\mathrm{X}_{1}$

$\mathrm{X}_{3}=$ Kepuasan Kerja

$\rho_{32}=$ Pengaruh $X_{3}$ dan $X_{2}$

$\mathrm{X}_{4} \quad=$ Loyalitas Kerja

$\rho_{41} \quad=$ Pengaruh $\mathrm{X}_{4}$ dan $\mathrm{X}_{1}$

$\mathrm{e}_{1} \quad=$ Koefesien resedu 1

$\rho_{42}=$ Pengaruh $\mathrm{X}_{4}$ dan $\mathrm{X}_{2}$

$\mathrm{e}_{2} \quad=$ Koefesien resedu 2

$\rho_{43}=$ Pengaruh $\mathrm{X}_{4}$ dan $\mathrm{X}_{3}$ 


\section{Pembahasan}

Hasil pengujian pertama penelitian menunjukkan bahwa variabel keteladanan kepala sekolah terhadap kepuasan kerja guru dimana besarnya koefisien jalur $\rho_{31}=0,31$ adalah 0,10. Artinya bahwa kekuatan keteladanan kepala sekolah secara langsung menentukan perubahan kepuasan kerja guru adalah sebesar $10 \%$. Hal ini mendukung teori yang yang dikemukakan Colquit dkk (2009 : 108) bahwa keteladanan kepala sekolah mempengaruhi secara langsung terhadap kepuasan kerja. Temuan ini membuktikan kepemimpinan kepala sekolah mempunyai peran penting dalam meningkatkan kepuasan kerja guru. Lebih lanjut hasil penelitian Sonedi (2016) bahwa kepemimpinan kepala sekolah memberikan pengaruh yang signifikan terhadap kepuasan kerja guru sebesar 22,5\%.Kepala sekolah memiliki tanggung jawab sebagai pemimpin untuk memperhatikan tingkat kepuasan kerja guru, demi terciptanya suasana kerja yang kondusif dalam mendukung tercapainya tujuan-tujuan organisasi.Kepala sekolah yang terbuka, suka mendengarkan dan bersahabat dan dapat melaksanakan kepemimpinannya dengan baik serta mengayomi bawahannya, tentunya akan memberikan perasaan senang dan nyaman bawahannya dalam bekerja bahkan bawahan akan mengeluarkan kualitas kerja maksimal dalam menyelesaikan tugas dan kewajibanya. Perasaan yang dirasakan tersebut perasaan puas, dimana akan tercermin dari cara guru menyikapi pekerjaannya, hasil dari kerja berhubungan erat dengan sikap guru terhadap pekerjaannya, situasi kerja dan kerja sama antara pemimpin dan semua guru.

Hasil pengujian kedua penelitian menunjukkan bahwa iklim kerja organisasi terhadap kepuasan kerja dimanakoefisien jalur $\rho_{32}=0,26$ sebesar $6,76 \%$, artinya semakin baik iklim organisasi suatu sekolah maka semakin tinggi pula kepuasan kerja guru. Hal ini mendukung dari hasil penelitian Surya dkk (2013) yaitu iklim kerja berpengaruh positif terhadap kepuasan kerja sebesar 11,22\%.Hasil penelitian Ahim Surachim dan Taufik Firdaus (2008) mengatakan bahwa iklim kerja organisasi mempunyai pengaruh yang positif terhadap kepuasan kerja sebesar $63 \%$.

Kepala sekolah memperhatikan iklim yang ada pada organisasi sekolah merupakan suatu gambaran bahwa pencapaian tujuan organisasi sekolah juga akan banyak ditentukan oleh bagaimana pengelolaan lingkungan sekolah sebagai pembentuk iklim organisasi sekolah, mendorong pada situasi yang kondusif bagi guru dan staf lainnya untuk melaksanakan tugasnya secara optimal.Persepsi guru akan kondisi lingkungan kerja di sekolah jelas akan menggambarkan bagaimana iklim organisasi sekolah, yang tentunya berdampak pada perilaku guru yang bersangkutan dalam menjalankan tugasnya. Disamping itu, fasilitas yang baik juga menciptakan iklim yang baik. Jadi kepala sekolah harus menciptakan suasana yang aman dan nyaman serta memahami apa yang menjadi kebutuhan mendasar guru sebagai bagian organisasi sekolah. Hal ini guru akan merasa puas terhadap pekerjaannya apabila sekolah tersebut memiliki iklim yang kondusif.

Hasil pengujian ketiga penelitian menunjukkan bahwa keteladanan kepala sekolah terhadap loyalitas kerja dimana koefisien jalur $\rho_{41}=0,23$ sebesar 5,29\%, artinya semakin baik keteladanan kepala sekolah maka semakin meningkat loyalitas kerja guru. Hal ini mendukung dari teori Colquit dkk (2009:108) bahwa keteladanan kepala sekolah mempengaruhi secara langsung terhadap loyalitas kerja guru. Hasil penelitian Ahmad Mubarok dan Susetyo Darmanto (2016) mengatakan bahwa kepemimpinan transformasional berpengaruh terhadap komitmen organisasi sebesar 8,35\%.

Dalam menjalankan kepemimpinannya kepala sekolah harus memiliki sifat teladan. Kepala sekolah harus memahami, menghayati, dan melaksanakan perannya sebagai manajer, memotivasi para guru untuk bekerja dan berlandaskan visi, mampu 
menciptakan suasana kekeluargaan dan menumbuhkan kreativitas, memperhatikan kesejahteraan, menciptakan tim work yang kompak dan cerdas, memberdayakan sekolahnya, dan kepala sekolah juga harus memiliki sifat percaya diri, ramah, kreatif, berwibawa, sabar, disiplin, bijakasana dan bertanggungjawab. Hal ini jika diterapkan oleh kepala sekolah dengan baik maka akan membawa sekolah kearah yang lebih baik, sehingga hal ini dampak yang positif bagi guru, dan guru akan setia (loyal) terhadap sekolah tersebut.

Hasil pengujian keempat penelitian menunjukkan bahwa iklim kerja organisasi terhadap loyalitas kerja dimana koefisien jalur $\rho_{42}=0,25$, sebesar $6,25 \%$, artinya semakin baik iklim organisasi suatu sekolah maka semakin tinggi pula loyalitas kerja guru. Hal ini mendukung dari penelitian Indah Mustika Dewi (2016) mengatakan iklim kerja berpengaruh positif terhadap loyalitas kerja karyawan sebesar 48,9\%.

Iklim yang kondusif bagi anggota organisasi mampu memberikan kenyamanan dalam bekerja, bahkan kemungkinan mereka bekerja akan bertahan dan loyal terhadap organisasi. Iklim kerja merupakan suatu kondisi atau keadaan suasana kerja yang berada di suatu organisasi sekolah yang dirasa nyaman, tenang, dan terpacu untuk bekerja lebih baik. Iklim kerja yang menyenangkan akan tercipta, apabila hubungan antar pegawai berkembang dengan harmonis. Dengan adanya suasana kerja yang nyaman dan tenang tersebut memungkinkan guru untuk bekerja lebih baik dan loyal terhadap organisasi. Kegiatan dan perilaku antar guru dan kepala sekolah sangat menentukan iklim di suatu lingkungan kerja. Kepala sekolah harus memperhatikan iklim kerja organisasi yang kondusif karena sangat mempengaruhi tingkah laku guru, pegawai, serta peserta didik.

Dengan demikian, hendaknya sekolah berkembang dinamis mengarah pada yang lebih baik untuk kelangsungan dan kemajuan pendidikan. Salah satu cara dalam pengembangan organisasi sekolah adalah tercapainya iklim kerja yang kondusif.

Hasil pengujian hipotesis kelima menunjukkan bahwa kepuasan kerja berpengaruh positif dan signifikan terhadap loyalitas kerja. Temuan penelitian menunjukkan bahwa variabel iklim kerja organisasi sekolah terhadap loyalitas kerja memberikan pengaruh koefisien jalur adalah $\rho_{43}=0,18$. Besar pengaruh iklim kerja organisasi terhadap loyalitas kerja sebesar 3,24\%, artinya semakin baik kepuasan kerja guru maka semakin tinggi pula loyalitas kerja guru. Hal ini mendukung dari penelitian Marseilly (2014) bahwa kepuasan kerja berpengaruh terhadap loyalitas kerja karyawan sebesar $71,1 \%$.

Guru yang termotivasi dalam bekerja adalah guru yang memiliki tingkat kepuasan tinggi dalam pekerjaannya. Sekolah harus memperhatikan kepuasan kerja guru karena hal ini akan mendorong kinerja dan loyalitas yang tinggi. Kepuasan kerja guru akan mencegah kepindahan, menguatkan motivasi, dan meningkatkan konstribusi guru. Pada akhirnya, guru yang puas akan menguntungkan sekolah di tempat dia bekerja.

Kepuasan kerja guru ditandai dengan munculnya rasa puas dan terselesaikannya tugas-tugas yang menjadi tanggung jawab guru tersebut tepat waktu. Disamping itu, munculnya dedikasi, kegairahan, kerajinan, ketekunan, inisatif dan kreativitas kerja yang tinggi dalam bekerja. Kepuasan kerja guru menjadi salah satu faktor yang harus diperhatikan, apabila guru merasakan kepuasan dalam bekerja, maka akan tercipta suasana yang penuh kebersamaan, memiliki tanggung jawab yang sama, iklim komunikasi yang baik dan juga semangat kerja yang tinggi. Tetapi sebaliknya apabila guru tidak merasa puas, maka akan tercipta suasana yang kaku, membosankan, semangat tim yang rendah dan guru akan merasa kurang loyal terhadap sekolah atau organisasi. 


\section{E. KESIMPULAN DAN SARAN}

\section{Kesimpulan}

1. Terdapat pengaruh langsung positif antara keteladanan kepala sekolah terhadap kepuasan kerja dengan ini $\rho_{31}=0,31$ dengan $t_{\text {hitung }}=4,49$ pada taraf $5 \%=1,98$. Hal ini menunjukkan bahwa peningkatan keteladanan kepala sekolah mengakibatkan terjadinya peningkatan kepuasan kerja guru SMP Swasta Kecamatan Medan Amplas.

2. Terdapat pengaruh langsung positif antara iklim kerja organisasi terhadap kepuasan kerja dengan ini $\rho_{32}=0,26$ dengan $t_{\text {hitung }}=3,64$. pada taraf $5 \%=1,98$. Hal ini menunjukkan bahwa peningkatan iklim kerja organisasi mengakibatkan terjadinya peningkatan kepuasan kerja guru SMP Swasta Kecamatan Medan Amplas.

3. Terdapat pengaruh langsung positif antara keteladanan kepala sekolah terhadap loyalitas kerja dengan ini $\rho_{41}=0,23$ dengan $t_{\text {hitung }}=3,14$. pada taraf $5 \%=1,98$. Hal ini menunjukkan bahwa peningkatan keteladanan kepala sekolah mengakibatkan terjadinya peningkatan loyalitas kerja guru SMP Swasta Kecamatan Medan Amplas.

4. Terdapat pengaruh langsung positif antara iklim kerja organisasi terhadap loyalitas kerja dengan ini $\rho_{42}=0,25$ dengan $t_{\text {hitung }}=3,53$. pada taraf $5 \%=1,98$. Hal ini menunjukkan bahwa peningkatan iklim kerja organisasi mengakibatkan terjadinya peningkatan loyalitas kerja guru SMP Swasta Kecamatan Medan Amplas.

5. Terdapat pengaruh langsung positif antara kepuasan kerja terhadap loyalitas kerja dengan ini $\rho_{43}=0,18$ dengan thitung $=2,38$. pada taraf $5 \%=1,98$. Hal ini menunjukkan bahwa peningkatan kepuasan kerja mengakibatkan terjadinya peningkatan loyalitas kerja guru SMP Swasta Kecamatan Medan Amplas.

\section{Saran}

Berdasarkan temuan penelitian, maka diajukan beberapa saran berikut untuk meningkatkan loyalitas kerja guru, yaitu:

1. Kepala sekolah sekolah harus profesional dan memiliki gagasan-gagasan inovatif untuk kemajuan sekolah, dan diharapkan mampu cekatan dalam pengambilan keputusan, selalu ceria dan profesional akan dijadikan contoh dan membangun kenyamanan sekolah. Selanjutnya Kepala sekolah diharapkan memperhatikan struktur tugas yang jelas, mampu menjembatani terjalinnya kerja sama dan komunikasi yang harmonis, keterbukaan dan membantu guru apabila ada kesulitan yang sedang dihadapi oleh sekolah.

2. Guru hendaknya membangun kerja sama, komunikasi yang terbuka, dan hubungan yang harmonis bagi sesama guru, sehingga apabila salah seorang guru menghadapi kesulitan dapat didiskusikan dan diselesaikan secara bersama, selalu berpikir positif terhadap kritik dan saran yang diberikan kepala sekolah dan rekan guru lainnya, dan menyadari bahwa pencapaian tujuan sekolah merupakan tanggung jawab bersama.

3. Dinas pendidikan hendaknya mendukung dan memberi kesempatan yang merata bagi guru untuk mengembangkan diri seperti memberi kesempatan bagi guru untuk melanjutkan pendidikan ke jenjang yang lebih tinggi dan memberikan reward kepada guru yang berprestasi, sebagai motivasi bagi guru yang bersangkutan dan bagi guru yang lain.

4. Bagi peneliti lain, perlu diadakan penelitian lebih lanjut tentang penelitian ini dengan variabel yang berbeda yang turut memberikan pengaruh terhadap loyalitas kerja guru, mengingat adanya keterbatasan dalam pelaksanaan penelitian dan hasil yang diperoleh belum maksimal. 


\section{F. DAFTAR PUSTAKA}

Akhyar, 2011. Hubungan Persepsi Tentang Kredibilitas Kepemimpinan Kepala Sekolah dan Motivasi Kerja dengan loyalitas Kerja Guru di SMA Negeri 2 Pematang Siantar.Tesis. 15 Desember 2011.

Colquitt, A. J., Lepine, J.A., dan Wesson, M.J., 2009. Organizational Behavior: Improving Performance and Commitment in the Workplace. New York: The McGraw-Hill Com., Inc.

Davis, K. dan Newstorm. 1996. Perilaku Dalam Organisasi. Edisi Tujuh. Jakarta: Erlangga

Gibson, R. 2002. Perilaku Organisasi (Konsep, Kontroversi, dan Aplikasi). Jakarta : Prenhalindo.

Handoko, T.H, 2000. Manajemen Personalia Dan Manajemen Sumber Daya Manusia. Jogjakarta : BPFE.

Hasibuan, S.P.M., 2005. Manajemen Sumber Daya Manusia. Jakarta : Bumi Aksara.

Newstrom, J.W., 2007. Organizatinal Behavior Human at Work. Twelfth Edition. New York : McGraw-Hill Companies. Inc.

Kinicki, A. dan Kreitner, R., 2001. Organizational Behaviour Key Concepts, Skills and Best Practices. Boston : Mc Graw-Hill Irwin.

Kouzes, J.M. dan Posner, B.Z., 1999. The Leadership Challenge (Tantangan Kepemimpinan. Penerjemah : Anton Adiwiyoto. Batam : Interaksara.

Luthans, F., 2011. Organizatinal Behavior. New York : McGraw-Hill Companies. Inc.

Muhammad, A., 2009. Komunikasi Organisasi. Jakarta : Bumi Aksara.

Mukhtar dan Iskandar. 2013. Orientasi Baru Supervisi Pendidikan. Jakarta: Gaung Persada Press Group

Mulyasa, E. 2002. Manajemen Berbasis Sekolah. Bandung: Rosdakarya.

Nitisemito, A. S. 1991. Manajemen Personalia. Jakarta. Gahalia Indonesia.

Poerwopoespito, F.Z. 2004. Mengatasi Krisis Manusia di Perusahaan. Jakarta. PT Gramedia Widiasarana Indonesia.

Purwanto, 2009. Evaluasi Hasil Belajar. Surakarta: Pustaka Belajar.

Rasimin, 2006. Manusia Dalam Industri dan Organisasi. Makalah. Yogyakarta: Fakultas Psikologi UGM.

Robbins, S.P. dan Judge, 2008, Perilaku Organisasi, Buku 2, Jakarta, Salemba.

Saydam, 1996. Manajemen Sumber Daya Manusia. Cetakan Pertama, , Jakarta: Penerbit Gunung Agung.

Siagian, S. P. 2003. Teori \& Praktek Kepemimpinan, Jakarta, Rineka Cipta.

Steers, M. R., 1977. Terjemahan Magdalena Jamin, Efektivitas Organisasi. Jakarta: Erlangga.

Sudimin, T, 2003. Whistleblowing: Dilema Loyalitas dan Tanggung Jawab Publik. Jurnal Manajemen dan Usahawan, 12 (11): 3-8

Wahjosmidjo, 2013. Kepemimpinan Kepala Sekolah : Tinjauan Teoretik dan Permasalahannya. Jakarta: Rajawali Pers.

Wirawan. 2013. Kepemimpinan. Teori, Psikologi, Prilaku Organisasi, Aplikasi dan Penelitian. Jakarta: PT. Raja Grafindo Persada

Zazin, N., 2011. Gerakan Menata Mutu Pendidikan : Teori \& Aplikasi. Jogjakarta : ArRuzz Media. 